\title{
Radiation Dosimeter Device
}

National Cancer Institute

\section{Source}

National Cancer Institute. Radiation Dosimeter Device. NCI Thesaurus. Code C150121.

A device that is used to measure the amount of ionizing radiation exposure or absorption. 